\title{
ANALYSIS OF MULTIPLE-ANGLE MICROWAVE OBSERVATIONS OF SNOW AND ICE USING CLUSTER-ANALYSIS TEGHNIQUES
}

\author{
By Stanley R. Rotman, Arthur D. Fisher, and David H. Staelin
}

(Research Laboratory of Electronics, Massachusetts Institute of Technology, Cambridge, Massachusetts 02139 , U.S.A.)

\begin{abstract}
The Nimbus-6 satellite carries the Scanning Microwave Spectrometer experiment (SCAMS) which continuously maps the Earth's surface at two frequencies $(22.235$ and $31.65 \mathrm{GHz})$ and at six angles besides nadir. Cluster analysis was applied to these observations to determine the influence of various geophysical parameters on the radiometric brightness temperatures.

Characteristic microwave signatures for a variety of terrain were obtained by this method; discrete clusters were distinguished for sea ice (with sub-classes for ice age and fractional ice cover) and firn (with accumulation-rate sub-classes). The availability of the angular data greatly facilitated separate determinations of the extent of continuous sea ice and mixtures of sea ice and water.

RÉsumé. Analyse d'observations aux micro-ondes sous des angles multiples de neige et de glace par les techniques de reconnaissance des formes. Le satellite Nimbus-6 transporte un spectromètre à balayage à micro-onde (Scanning Microwave Spectrometer - SCAMS) qui cartographie continuellement la surface de la terre à deux fréquences $(22,235$ et $31,65 \mathrm{GHz})$ et sous six angles en sus du nadir. On a appliqué l'analyse de groupe à ces observations pour déterminer l'influence de paramètres géophysiques variés sur les températures de brillance radiométrique.

On a obtenu par cette méthode les signatures caractéristiques aux micro-ondes pour divers terrains; on a distingué des groupes spéciaux pour la glace de mer (qui se subdivisent selon l'âge de la glace et le découpage de la couverture de glace) et le névé (avec des sous-classes selon la vitesse d'accumulation). Le fait de disposer de données prises sous divers angles facilite beaucoup la distinction des étendues à glace de mer noninterrompue et des mélanges de glace de mer et d'eau.

Zusammenfassung. Analyse von Beobachtungen mit Mikrowellenabtastern über Schnee und Eis unter Anwendung von Verfahren der Mustererkennung. Der Satellit Nimbus-6 trägt das Mikrowellen-Abtasterspektrometer (SCAMS), das die Erdoberfläche dauernd in zwei Frequenzen (22,235 und $31,65 \mathrm{GHz}$ ) und unter sieben Nadirdistanzen aufnimmt. Zur Bestimmung des Einflusses verschiedener geophysikalischer Grössen auf die radiometrischen Strahlungstemperaturen wurde die Cluster-Analyse angewandt.

Für eine Reihe von Oberflächen liessen sich charakteristische Mikrowellen-Signaturen feststellen; Meereis (mit Unterklassen für Alter und Dichtigkeit) und Firn (mit Unterklassen für die Akkumulationsrate) ergaben diskrete Häufungsstellen (Cluster). Die Verfügbarkeit der. Winkeldaten erleichtert getrennte Bestimmungen des Vorkommens von geschlossenem Meereis und Mischlagen von Meereis und Wasser erheblich.
\end{abstract}

\section{INTRODUGTION}

The extent and nature of the polar ice sheets are of interest to workers in a variety of fields, particularly climatology and navigation. Passive microwave radiation observations of the Arctic and Antarctic have been used successfully in mapping the spatial and temporal evolution of the ice-water boundary and the percentage of old ice as opposed to new ice (Campbell and others, 1974, 1975; Gloersen and others, I978). Differences in the microwave signatures between old ice, new ice, and water have also been observed (Wilheit and others, 1972; Gloersen and others, 1973; Tooma and others, 1975). Moreover, the long-term snow-accumulation rates for Greenland and Antarctica have been estimated from microwave signatures (Zwally, 1977; Rotman and others, in press).

Cluster-analysis techniques were applied to satellite observations of brightness temperature at two frequencies $v(22.235$ and $3 \mathrm{I} .65 \mathrm{GHz})$ and seven angles $\theta$ over the polar regions, (lat. $70-80^{\circ}$, north and south); thus I4-dimensional feature vectors were formed. Unsupervised "hierarchical" techniques were employed (making no a priori assumptions about the possible classes) in order to study the basic information content of these data (Nagy, I968). Well-defined clusters were produced which tended to include data from points in geographical proximity. In fact, the clustering process effectively performed automatic pattern recognition for a variety of snow and ice classes. Additionally, the average of all the data in each class at a 
given angle $\theta$ and frequency $\nu$ provided typical brightness-temperature "signatures" $\mathcal{T}_{\mathrm{b}}(\theta, \nu)$ for the various snow and ice types (Fisher and others, [1978]). The angular data have proven efficient in distinguishing mixtures of new ice with water from uniform old ice. This longstanding problem is encountered when observations at only a single angle are employed, because the brightness temperature for some mixtures of new ice and water can be identical with that for old ice (Gloersen and others, 1974; Webster and others, 1975).

\section{SATEllite AND GRound-TRUth DATA}

The Scanning Microwave Spectrometer (SCAMS) on board the Nimbus-6 satellite observed the Earth's surface at 22.235 and 3 r.65 GHz from July r 975 to May 1976 . At these frequencies, the Earth's surface was mapped with spatial resolutions of $145 \mathrm{~km}$ near nadir and $330 \mathrm{~km}$ at the scan limit; the seven angles $\theta$ from the satellite relative to nadir were: $0.0^{\circ}$, $7.2^{\circ}, 14.4^{\circ}, 21.6^{\circ}, 28.8^{\circ}, 36.0^{\circ}$, and $43.2^{\circ}$ (Staelin and others, 1977). Because SCAMS incorporated a rotating mirror, the polarization vector rotated with scan angle $\theta$ such that the observed brightness temperature $T_{\mathrm{b}}$ was $T_{\mathrm{h}} \cos ^{2} \theta+T_{\mathrm{v}} \sin ^{2} \theta$, where $T_{\mathrm{h}}$ and $T_{\mathrm{v}}$ were the brightness temperatures due to the horizontally and vertically polarized radiation components respectively. Due to the Earth's curvature, the zenith angles of observation $\phi$ at the terrestrial surface were $0.0^{\circ}, 8.4^{\circ}, 16.9^{\circ}, 25.6^{\circ}, 34.4^{\circ}, 43.5^{\circ}$, and $53.3^{\circ}$.

Fourteen-dimensional "feature vectors" (brightness temperatures from seven angles at two frequencies) were generated from the satellite observations for 900 locations in the Arctic and 900 in the Antarctic at each of three periods (approximately one-week intervals in September, November, and January). After vectors with missing components were excluded, approximately seven hundred valid vectors remained from each of the original data sets.

The results of our analysis of the microwave data were compared with the actual known surface conditions. Knowledge of this ground truth was available from two sources. First, long-term data were available for the accumulation rate of snow in Antarctica and Greenland (Fristrup, 1966, p. 234; Bentley and others, r 964) and for the extent of the permanent ice pack (Brush and others, I966, p. I80). Second, seasonal data for the partial ice cover in the Arctic and Antarctic have been obtained for specific years (U.S. Navy Dept. Fleet Weather Facility, [1976[a], [b]], [1977]) based on the ESMR radiometers on the Nimbus-5 and Nimbus-6 satellites (Gloersen and others, 1974) and on ground observations.

\section{Clustering theory}

The overall objective of cluster analysis is to lump "similar" feature vectors into a common class, while dissimilar feature vectors are placed in distinct classes (Nagy, I968).

An agglomerative hierarchical approach was employed in which the clustering process was initiated by treating each vector as a one-member cluster. The Euclidian distance between each possible pair of vectors in the data set was computed and stored as a "similarity" measure. Then the similarity threshold for which two clusters are combined was increased monotonically to form new clusters, until all the vectors in the data set were combined into one cluster. All the clusters at a given intermediate threshold could be reproduced later. Many options exist for computing the distances between newly formed clusters; the techniques used were single-link and complete-link clustering. In the complete-link approach, the similarity between any two clusters is taken as the furthest Euclidian distance between the elements (I4-dimensional vectors) in each cluster; in single-link clustering, the least distance is used (Anderberg, r973).

Once the clusters were formed, two processing methods were used. First, contours of clusters at various distance thresholds were replotted into the geographic maps of Antarctica and Greenland. Second, signatures were created for each cluster by plotting the mean values of the brightness temperatures as a function of angle for both $3^{1}$ and $22 \mathrm{GHz}$. 
These unsupervised clustering techniques have the advantage of providing an "objective" indication of the information embedded in the basic variation of brightness temperature with angle and frequency. No theoretical model or a priori information is employed. There is a danger that the primary data $\tau_{\mathbf{b}}(\theta, \nu)$ represent such a complex mixture of meaningful parameters that mere position in 14 -dimensional feature space will have no bearing on the kinds of information desired. However, a variety of techniques can be employed to evaluate the clusters. In particular, geographically connected areas should tend to be grouped in the same class since neighboring areas will often have the same physical characteristics; the clusters should indicate physically meaningful geographic areas. For example, clusters should follow contours of constant accumulation and temperature-or combinations thereof-of the icewater boundary.

Moreover, reduction of the size of our vector space is possible by using the KarhunenLoève method (Duda and Hart, 1973). In this analysis, the correlation matrix is computed, and the coordinate system is then rotated to point along orthogonal trends in the data set. Preliminary studies show that our I4-dimensional data set can be reduced to seven dimensions in this newly rotated coordinate system without losing significant information (Fisher and others, [1978]); these seven orthogonal vectors have no simple relationship to identifiable physical parameters.

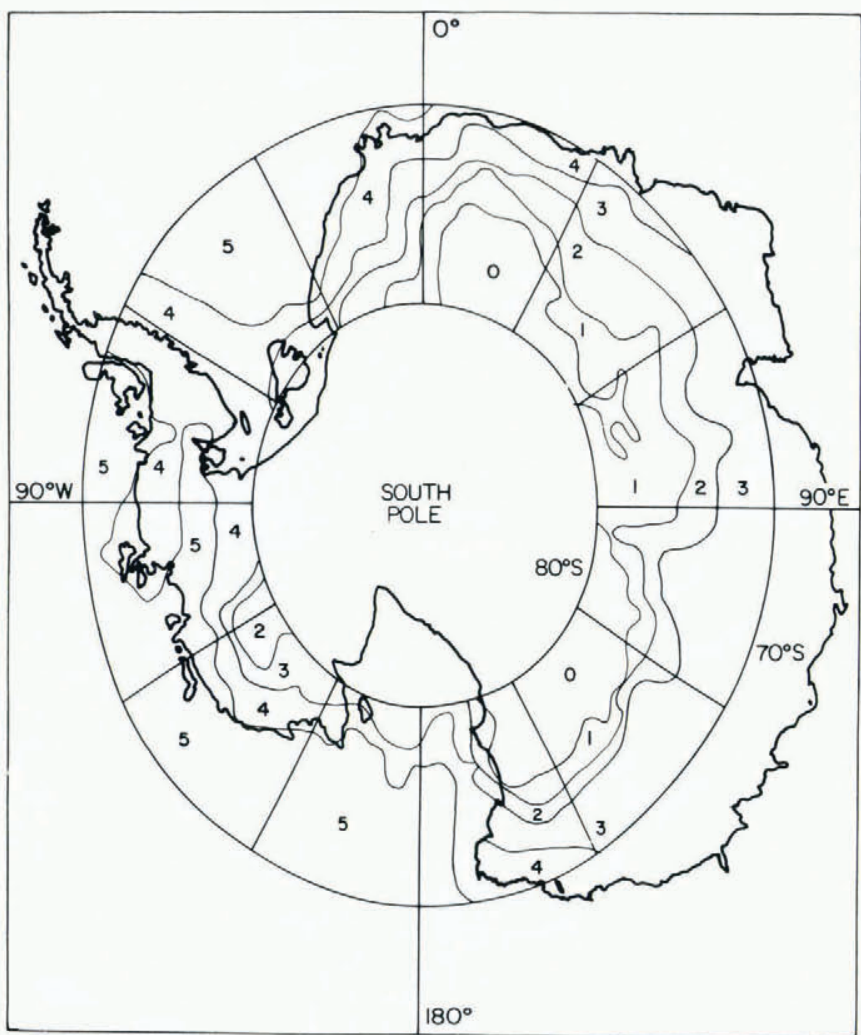

Fig. I. Map of the Antarctic region for September 1975 with six clusters (elliptical projection). The symbols for different clusters are arbitrary. 


\section{EXPERIMENTAL RESUlTS}

Excellent results were obtained for the clustering of the brightness-temperature data. Distinct geographical clusters appeared for both the Arctic and Antarctic regions for all three seasons with both complete- and single-link clustering. The maps presented in this paper were produced by complete-link clustering.

Figure I shows Antarctica in September 1975 (winter in this area) with six clusters within the latitudes of $70^{\circ}$ to $80^{\circ} \mathrm{S}$. The band structure of the clusters in Eastern Antarctica is closely related to the accumulation rate and temperature contours (which to some extent are correlated with each other) as determined by surface information and other satellite observations (Rotman and others, in press; Bentley and others, 1964). A cluster which seems to represent the lowest accumulation-rate areas, formed in the regions (I) lat. $76^{\circ}$ to $79^{\circ} \mathrm{S}$., long. $30^{\circ} \mathrm{E}$., and (2) lat. $76^{\circ}$ to $79^{\circ} \mathrm{S}$., long. $140^{\circ} \mathrm{E}$. (symbol "o"). Clusters "o", "I", "2", " 3 ", and " 4 " represent the areas of firn in Eastern Antarctica in order of increasing accumulation rate and temperature as determined from ground data (Bentley and others, 1964). Cluster " 4 " is also firn in Western Antarctica with a slight overlap onto sea ice. The area of low accumulation rate at approximately $120^{\circ} \mathrm{W} ., 78-79^{\circ} \mathrm{S}$., stands out clearly. Sea ice is shown by cluster " 5 ".

In Figure 2, the data from the Arctic region are grouped into 14 clusters for November 1975. The clustering contours in Greenland (clusters " 0 "- " 5 ") seem to follow accumulation

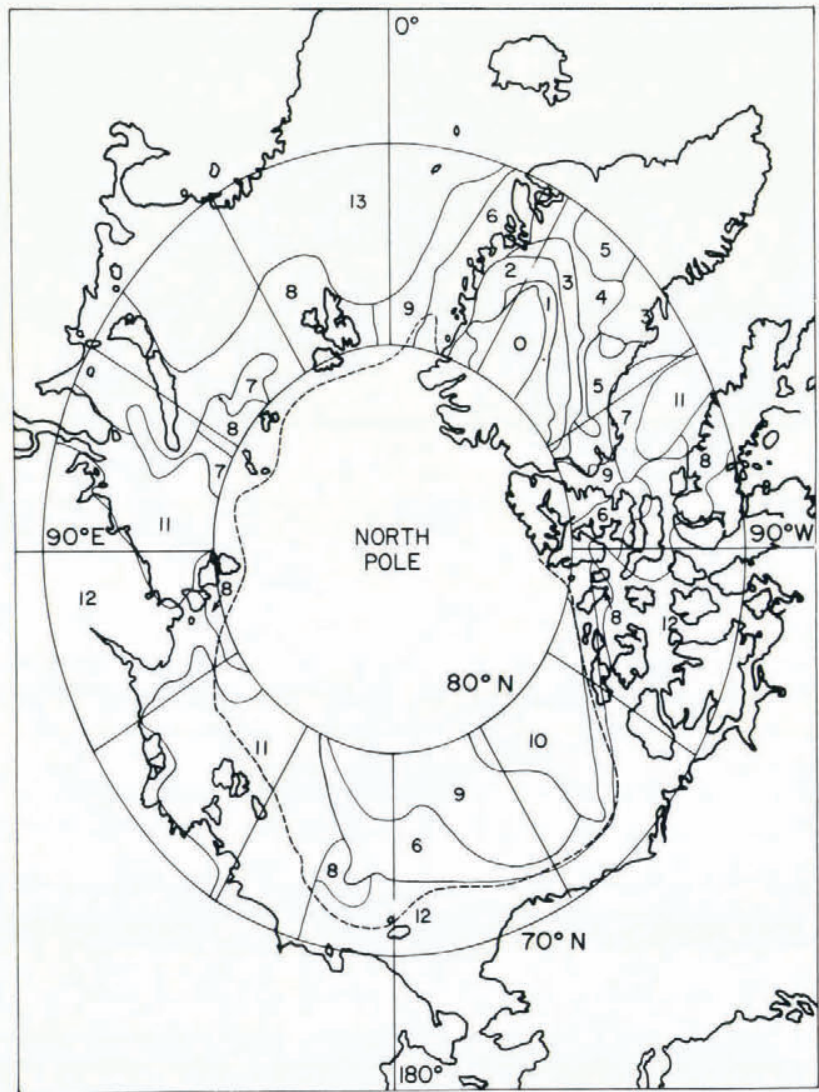

Fig. 2. Map of the Arctic region for November 1975 with fourteen clusters. 
contours rather than temperature contours (Fristrup, 1966, p. 230; Gloersen and others, 1974; Zwally, 1977). Clusters "6", “9", and "10" are representative of the permanent ice pack; its outline is indicated in Figure 2 by the broken line, as determined from ground-truth observations (Brush and others, I966, p. 180). Old sea ice is also found east of Greenland, as shown by the presence of data points grouped into clusters " 6 " and " 9 ". The open expanses of water are indicated by the low brightness temperature of cluster " 13 "; bare ground in Siberia is contained in cluster " 12 ".

The mean values of the brightness temperatures for each cluster were plotted as a function of angle. Typical signatures can be seen in Figures 3, 4, 5, and 6. Observations of the surface show the following general order of increasing brightness temperatures: (I) water, (2) firn (brightness temperature increasing with accumulation), (3) multi-year sea ice (brightness temperature decreasing with age), (4) first-year ice, and (5) bare ground. The shapes of the

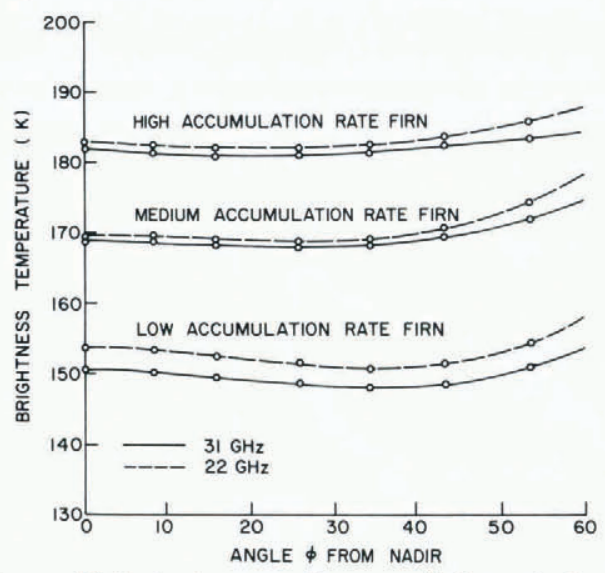

Fig. 3. Typical microwave signatures of Antarctic firn for September 1975 (clusters " 0 ", " $I$ ", and " 3 " from Figure I for low, medium, and high accumulation rates, respectively).

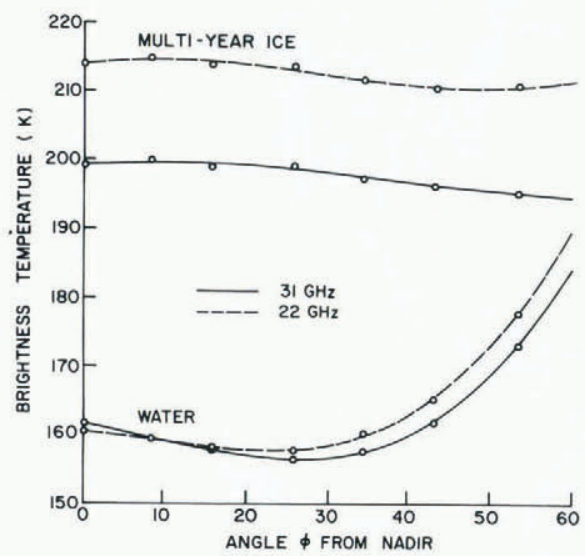

Fig. 5. Typical microwave signatures of Arctic multi-year sea ice and water for September 1975 (clusters "IO" and "I3" from Figure 2 for multi-year sea ice and water, respectively).

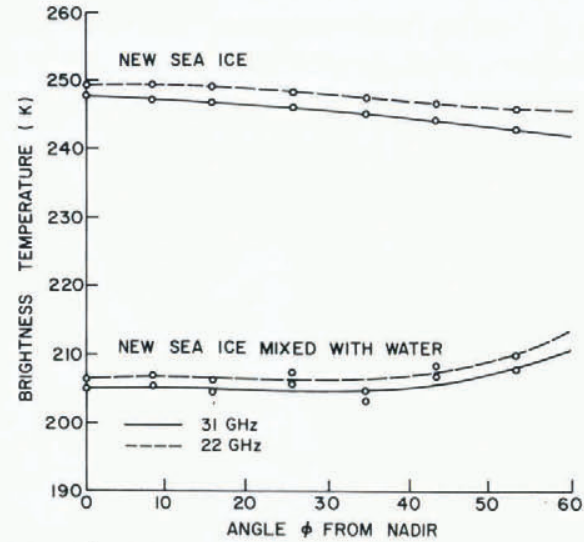

Fig. 4. Typical microwave signatures of Antarctic new sea ice and Arctic new sea ice mixed with water for September 1975 (cluster " 5 " from Figure I for Antarctic new sea ice; cluster " $I I$ " from Figure 2 for Arctic new sea ice mixed with water).

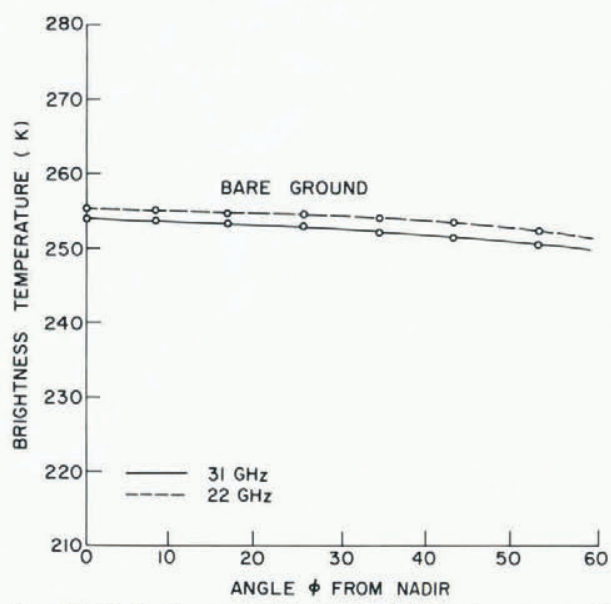

Fig. 6. Typical microwave signature of Arctic bare ground for September 1975 (cluster "I2" from Figure 2). 
curves are very informative although separate polarization information is lacking. Additional study of these signatures should clarify the degree to which the volume-scattering in the medium arises from spherical or layered inhomogeneities (Tsang and Kong, 1975, 1976; Chang and others, 1976; Fisher, 1977).

\section{Appligations}

Microwave signatures can differentiate between new sea ice mixed with water and old sea ice. This distinction is difficult to obtain from nadir data alone. Since the brightness temperature of new sea ice is very high ( $240 \mathrm{~K}$ ) and that from water relatively low ( $160 \mathrm{~K}$ ), an equal mixture of the two will be approximately $200 \mathrm{~K}$, which is the same temperature as old sea ice. However, the angular data will differ for the two surfaces since the brightness temperature of a mixture of new sea ice and water shows an increase with angle from nadir, corresponding to the behavior for sea-water alone (Edgerton and others, 197I), while that of multi-year sea ice decreases.

A simple algorithm was developed to classify SCAMS observations as originating from either old ice or a mixture of new ice and water. Each experimental vector was compared to

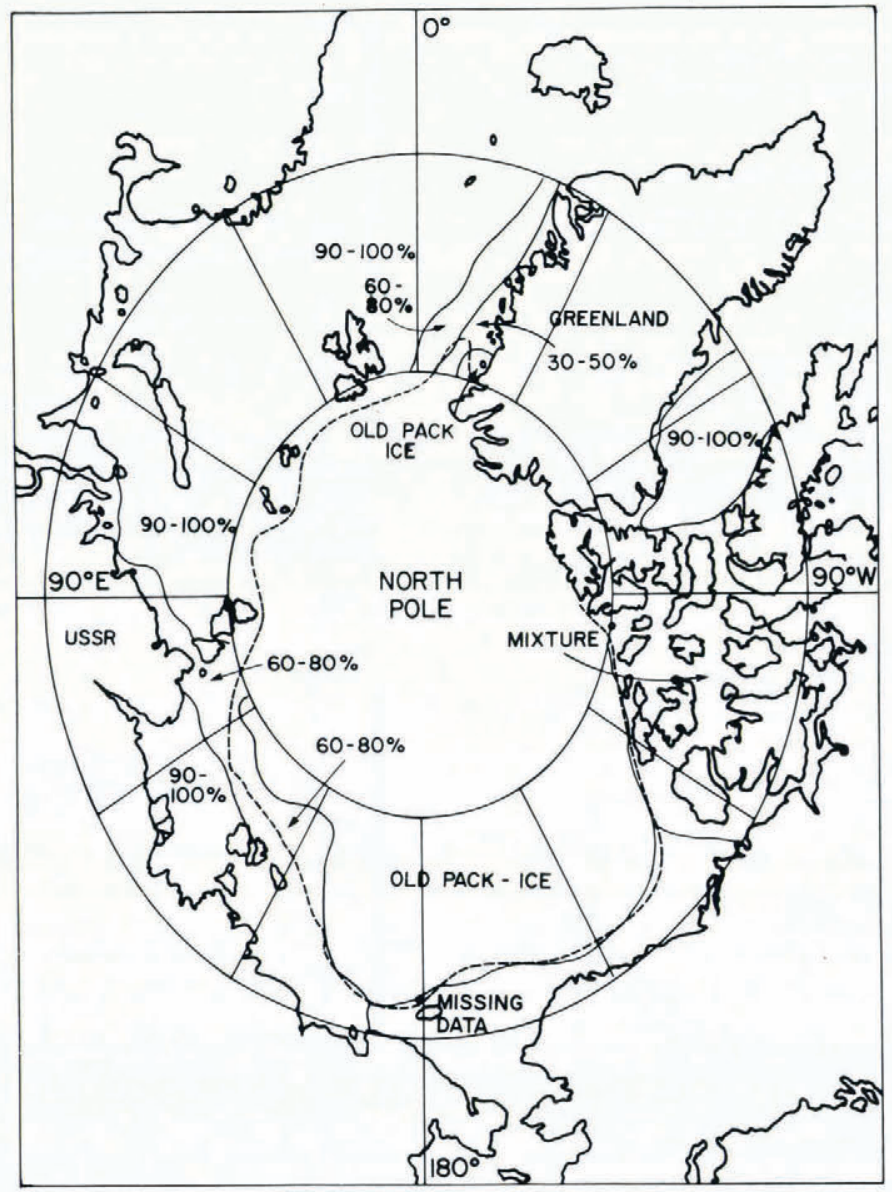

Fig. 7. The partial ice cover of the Arctic region derived from microwave data between lat. $70^{\circ}-80^{\circ}$ N. for September 1975 . Percentages shown are the amounts of open water compared to sea ice within each resolution cell of the radiometer (I5o km by $150 \mathrm{~km}$ ) in increments of $10 \%$. The dashed line is the multi-year sea-ice limit (Brush and others, 1966, p. 180). 
theoretical signatures for a mixture of new ice and water and assigned to that percentage of new ice with which it best agreed in a least-squares sense. Then the experimental signatures were tested to determine whether they represent old ice or a mixture of new ice and water. Their angular variations were compared to the angular variations of the signature which was obtained previously for the ice-water mixture and to those of the signature for old ice. In this last comparison, the average brightness temperature over all angles was eliminated from the signatures. This reduced the effects of variations of physical temperatures.

Figure 7 shows these results for the North Pole in September; they agree well with the permanent ice pack which is known to exist between long. $120^{\circ} \mathrm{E}$. and $120^{\circ} \mathrm{W}$. and at long. $20^{\circ} \mathrm{W}$. (Campbell and others, 1975; Brush and others, I966, p. I8o). Mixtures of ice and water appear to the east of Greenland while wide expanses of water appear between long. $0^{\circ}$ and $90^{\circ} \mathrm{W}$. and at long. $60^{\circ} \mathrm{E}$.

Figure 8 shows the seasonal changes from Figure 7 for the North Pole region in January. As we would expect, the area of permanent ice pack has not grown over the winter. However, new sea ice now replaces the open water or partial ice cover seen in September at long. $70^{\circ} \mathrm{W}$. and $60^{\circ}$ to $120^{\circ} \mathrm{E}$. The partial ice cover located east of Greenland has expanded; open water still remains north of Norway. These seasonal observations agree well with ground observations (U.S. Navy Dept. Fleet Weather Facility, [1976[a], [b]], [1977]). It is interesting to

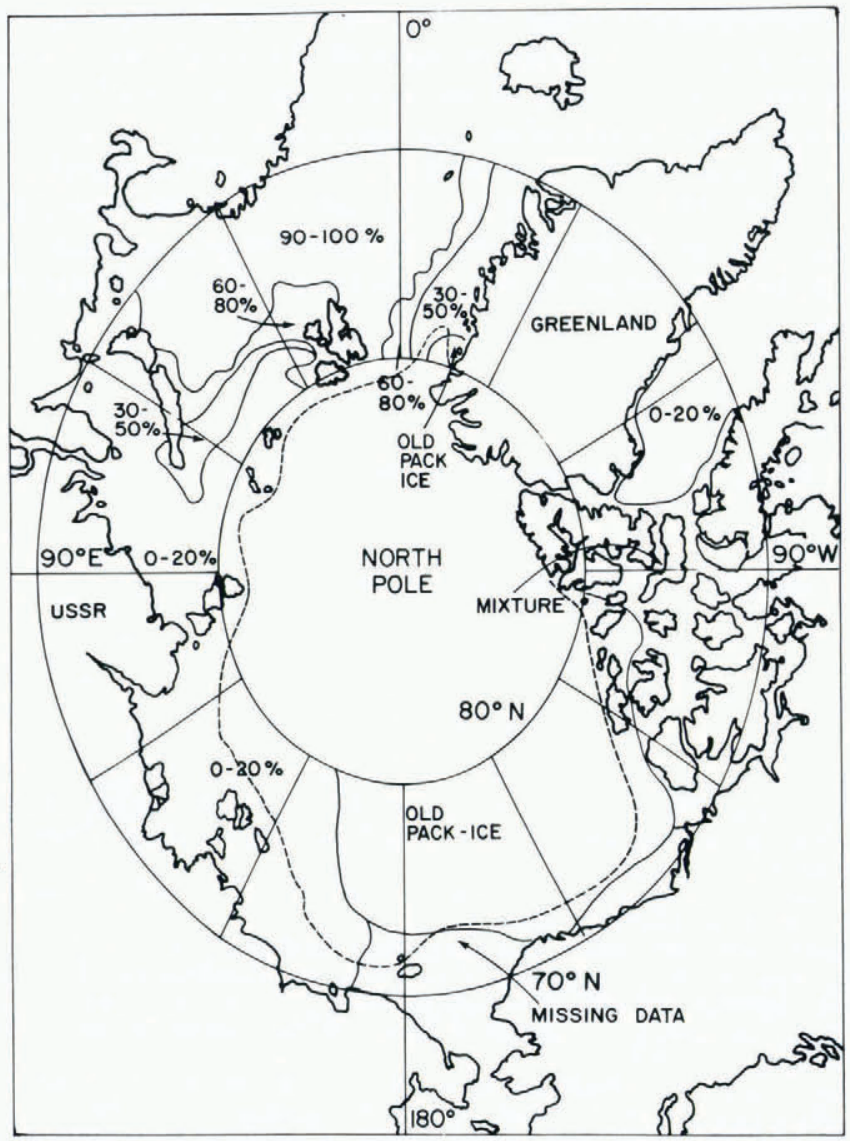

Fig. 8. The partial ice cover of the Arctic region derived from SCAMS data between lat. $70^{\circ}-80^{\circ} \mathrm{N}$. for fanuary 1976 . 
note that most of the non-permanent ice-pack area is either $c .100 \%$ new ice or $c .100 \%$ water; mixtures comprise only c. 10\% of the observed area.

Moreover, the age of the permanent ice pack can be determined by its brightness temperature. As the ice ages, the brightness temperature decreases (Figs 4 and 5 ) while the temperature difference between the 22 and 31 GHz signatures increases strongly (Kunzi and others, 1976; Campbell and others, I978). One possible explanation of these effects is that the brine drains from the ice, gradually creating empty voids and increasing the volume scattering. This would account for the observed frequency dependence and the decrease in brightness temperature. Analysis of the microwave data indicates that, as one travels eastward from long. $150^{\circ} \mathrm{W}$. to $120^{\circ} \mathrm{E}$., the brightness temperature of the permanent ice decreases while the difference between the brightness temperatures at the two microwave frequencies increases (Kunzi and others, 1976). This observation is consistent with a progressive aging of the ice with longitude from west to east.

\section{SUMMARY AND CONCLUSIONS}

Through automatic pattern-recognition techniques, microwave observations of the Arctic and Antarctic regions have been analyzed and found to cluster in accordance with the type of terrain. The microwave signatures of ice and snow surfaces have been observed at seven angles, including nadir, and at two frequencies $(22.2$ and $31.6 \mathrm{GHz})$. For both polar regions, examination of the characteristic curves for firn, sea ice, and water showed that valuable information is contained in the angular changes of the brightness temperatures. These observations enabled the determination of the percentage of partial ice coverage and the discrimination of old ice from mixtures of new ice and water. Models have been developed to relate brightness temperatures to volume scattering (Tsang and Kong, 1975, 1976; Chang and others, 1976; Fisher, 1977). It is expected that the use of these theories, particularly through the inclusion of anisotropic scattering effects, will prove helpful not only in explaining the available observations, but also for interpreting new data which are becoming available from the Nimbus-7 satellite.

\section{Acknowledgement}

We thank Leung Tsang for many useful discussions. This work was supported by NASA Contract $\mathrm{NAS}_{5-2}$ ig8o.

MS. received ${ }_{1} 6$ July 1979 and in revised form 4 December 1979

\section{REFERENCES}

Anderberg, M. R. 1973. Cluster analysis for applications. New York, Academic Press.

Bentley, C. R., and others. I964. Physical characteristics of the Antarctic ice sheet, by C. R. Bentley, R. L. Cameron, C. [B. B.] Bull, K. Kojima, and A. J. Gow. Antarctic Map Folio Series (New York, American Geographical Society), Folio 2.

Brush, J. E., and others. 1966. The Odyssey world atlas, by F. E. Brush [and ${ }_{3} 3$ others]. New York, Odyssey Books, Trade Division of Western Publishing Co., Inc.

Campbell, W. J., and others. 1974. Dynamics and morphology of Beaufort Sea ice determined from satellites, aircraft, and drifting stations, by W. J. Campbell, P. Gloersen, W. Nordberg, and T. T. Wilheit. (In Bock, P., and others, ed. COSPAR. Approaches to Earth survey problems through use of space techniques. Proceedings of the symposium held in Constance, F.R.G., 23-25 May 1973. Edited by P. Bock, with the assistance of F. W. G. Baker and S. Ruttenberg. Berlin, Akademie-Verlag, p. 3 I $1-27$.)

Campbell, W. J., and others. 1975. Geophysical studies of floating ice by remote sensing, by W. J. Campbell, W. F. Weeks, R. O. Ramseier, and P. Gloersen. Journal of Glaciology, Vol. I 5, No. 73, p. 305-28.

Campbell, W. J., and others. I978. Microwave remote sensing of sea ice in the AIDJEX main experiment, by W. J. Campbell [and 19 others]. Boundary-Layer Meteorology, Vol. 13, Nos. I-4, p. 309-37. 
Chang, A. T. C., and others. 1976. Microwave emission from snow and glacier ice, by [A.] T. C. Chang, P. Gloersen, T. [J.] Schmugge, T. T. Wilheit, and H. J. Zwally. Journal of Glaciology, Vol. 16, No. 74, p. 23-39.

Duda, R. O., and Hart, P. E. 1973. Pattern classification and scene analysis. New York, John Wiley and Sons, Inc. Edgerton, A. T., and others. 1971. Microwave emission characteristics of natural materials and the environment, by A. T. Edgerton, F. Ruskey, D. Williams, A. Stogryn, G. Poe, D. Meeks, O. Russell. El Monte, California, Microwave Division, Aerojet-General Corporation.

Fisher, A. D. 1977. A model for microwave intensity propagation in an inhomogeneous medium. IEEE Transactions on Antennas and Propagation, Vol. AP-25, No. 6, p. 876-82.

Fisher, A. D., and others. [1978.] An analysis of microwave remote sensing data by pattern recognition techniques, [by] A. D. Fisher, S. [R.] Rotman, and D. H. Staelin. United States National Committee, International Union of Radio Science. National Radio Science Meeting, 9-13 Fanuary 1978 , University of Colorado at Boulder, Boulder, Colorado,
U.S.A., p. 1 1 8. [Abstract.]

Fristrup, B. 1966. The Greenland ice cap. København, Rhodos.

Gloersen, P., and others. 1973. Microwave signatures of first-year and multiyear sea ice, [by] P. Gloersen, W. Nordberg, T. J. Schmugge, and T. T. Wilheit, [and] W. J. Campbell. Journal of Geophysical Research, Vol. 78, No. 18, p. $3564-72$.

Gloersen, P., and others. I974. Microwave maps of the polar ice of the Earth, [by] P. Gloersen, T. T. Wilheit, [A.] T. C. Chang and W. Nordberg and W. J. Campbell. Bulletin of the American Meteorological Society, Vol. 55, No. 12 , p. $1442-48$.

Gloersen, P., and others. 1978. Time-dependence of sea-ice concentration and multilayer ice fraction in the Arctic basin, by P. Gloersen, H. J. Zwally, A. T. C. Chang and D. K. Hall, W. J. Campbell and R. O. Ramseier. Boundary-Layer Meteorology, Vol. 13 , Nos. 1-4, p. 339-59.

Kunzi, K. F., and others. 1976. Snow and ice surfaces measured by the Nimbus 5 microwave spectrometer, [by] K. F. Kunzi, A. D. Fisher and D. H. Staelin, J. W. Waters. Journal of Geophysical Research, Vol. 81, No. 27, p. $4965-8$ o.

Nagy, G. 1968. State of the art in pattern recognition. Proceedings of the IEEE, Vol. 56, No. 5, p. 836-62.

Rotman, S. R., and others. In press. Inversion for physical characteristics of snow using passive radiometric observations, by S. R. Rotman, A. D. Fisher, and D. H. Staelin. Journal of Glaciology.

Staelin, D. H., and others. 1977. Microwave spectroscopic imagery of the Earth, by D. H. Staelin, P. W. Rosenkranz, F. T. Barath, E. J. Johnston, and J. W. Waters. Science, Vol. 197, No. 4307, p. $991-93$.

Tooma, S. G., and others. 1975. Comparison of sea-ice type identification between airborne dual-frequency passive microwave radiometry and standard laser/infrared techniques, by S. G. Tooma, R. A. Mennella, J. P. Hollinger, and R. D. Ketchum, Jr. Fournal of Glaciology, Vol. I 5, No. 73, p. 225-39.

Tsang, L., and Kong, J. A. 1975. The brightness temperature of a half-space random medium with nonuniform temperature profile. Radio Science, Vol. 10, No. 12, p. 1025-33.

Tsang, L., and Kong, J. A. 1976. Thermal microwave emission from half-space random media. Radio Science, Vol. I I, No. 7, p. 599-6o9.

U.S. Navy Dept. Fleet Weather Facility. [1976[a].] Eastern Arctic sea ice analyses, 1972-1975. Alexandria, Virginia, Defense Documentation Center, Defense Logistics Agency, Cameron Station. (Technical Report AD Ao33344.)

U.S. Navy Dept. Fleet Weather Facility. [1976[b].] Western Arctic sea ice analyses, 1972-1975. Alexandria, Virginia, Defense Documentation Center, Defense Logistics Agency, Cameron Station. (Technical Report AD Ao33345.)

U.S. Navy Dept. Fleet Weather Facility. [1977.] Eastern-western Arctic sea ice analyses, 1976. Alexandria, Virginia, Defense Documentation Center, Defense Logistics Agency, Cameron Station. (Technical Report AD A043353.)

Webster, W. J., jr, and others. 1975. A radio picture of the Earth, by W. J. Webster, Jr, T. T. Wilheit, [A.] T. C. Chang, P. Gloersen, and T. J. Schmugge. Sky and Telescope, Vol. 49, No. 1, p. 14-16.

Wilheit, T. T., and others. I972. Aircraft measurements of microwave emission from Arctic sea ice, [by] T. [T.] Wilheit and W. Nordberg, J. [C.] Blinn, W. [J.] Campbell, and A. [T.] Edgerton. Remote Sensing of Environment, Vol. 2, No. 3, p. 129-39.

Zwally, H. J. 1977. Microwave emissivity and accumulation rate of polar firn. Fournal of Glaciology, Vol. 18, No. 79 , p. 195-215. 